\title{
Lipid metabolism in farm animals
}

\author{
By R. G. Vernon and D. J. Flint, Hannah Research Institute, Ayr KA6 5HL
}

In this brief review of lipid metabolism in farm animals we have focussed on aspects (in particular triacylglycerol production) which are of importance in their use for human consumption. Also, as lipid metabolism is very similar in all mammals, with variations arising primarily from differences in diet, we have concentrated on domestic ruminants. Cattle and sheep are herbivores but like all mammals they are unable to digest cellulose, the major carbohydrate moiety of leaves and shoots. This problem has been resolved in herbivores by the development of modifications to the digestive tract to slow down the passage of nutrients and by acquisition of a microbial population within the digestive tract which can digest cellulose. In some species (e.g. horse, rabbit) the microbes are located primarily in an extension of the hind-gut, but in cattle and sheep there is a major extension of the gut proximal to the stomach (the rumen) which houses the microbes. Thus, in cattle and sheep dietary nutrients are exposed to the activities of microorganisms before entry into the true stomach (abomasum). This, as described below, has considerable implications for lipid metabolism in these animals. In contrast, lipid metabolism in pigs is very similar to that in humans (see Gurr, 1988): both are omnivores and are simple-stomached. In the pig, as in man, the fatty acid composition of triacylglycerols can be modulated readily by dietary means. Much more detailed accounts of lipid metabolism in farm animals can be found in Lipid Metabolism in Ruminant Animals (Christie, 1981a) and Fats in Animal Nutrition (Wiseman, 1984).

\section{Digestion and absorption of dietary lipids}

The lipid content of the fresh and also dried forages consumed by cattle and sheep is relatively low (50-100 g lipid/kg dry plant tissue) and is rich in polyunsaturated fatty acids, especially linolenic acid (Table 1 ). Such diets are usually supplemented with 'concentrates': cereals which are again low in lipid content but rich in polyunsaturated fatty acids (Table 1). In the rumen, lipids are hydrolysed and the released fatty acids are extensively biohydrogenated by the microbial population, about $90 \%$ of dietary linoleic acid being lost through this process (see Moore \& Christie, 1984), while there is a major increase in the amount of stearic acid (Table 1). The unesterified fatty acids are adsorbed onto particulate matter within the rumen and pass in this form into the abomasum (See Harfoot, 1981): there is essentially no absorption of fatty acids from the rumen. There is some de novo synthesis of lipids by rumen micro-organisms (see Harfoot, 1981) which also pass into the abomasum; hence the amount of lipid and fatty acid entering the abomasum usually exceeds that ingested (see Moore \& Christie, 1984).

Rumen micro-organisms are killed in the abomasum and their lipids are released. These and the dietary fatty acids pass through into the duodenum where they mix with secretions from the pancreas (containing lipases and phospholipases) and bile which contains lipid ( $80 \%$ phosphatidyl choline) and bile acids (predominantly taurine conjugates) (see Noble, 1981; Moore \& Christie, 1984). The lipases and phospholipases partly hydrolyse the microbial lipids and any dietary lipid which escaped hydrolysis in the rumen. The latter is normally very little unless the animals are given lipid supplements treated to prevent their metabolism in the rumen (see Noble, 1981). The amount of lipid in the duodenum is increased substantially by bile lipids (in sheep $30-40 \mathrm{~g}$ dietary fatty acid entering the duodenum/d is augmented by $10-15 \mathrm{~g}$ biliary lipid; see Noble, 1981). 
Table 1. Fatty acid composition of dietary constituents, rumen contents and lymph triacylglycerols in sheep

(Values are expressed as $\mathrm{g}$ fatty acid/100 $\mathrm{g}$ total fatty acids and are taken from Harfoot (1981) or Christie (1981b))

\begin{tabular}{|c|c|c|c|c|c|}
\hline \multirow[b]{2}{*}{ Fatty acid } & \multicolumn{4}{|c|}{ Total lipids } & \multirow{2}{*}{$\begin{array}{c}\text { Triacylglycerols } \\
\text { Lymph }\end{array}$} \\
\hline & Grass & Hay & Concentrates & Rumen contents & \\
\hline \multicolumn{6}{|l|}{ Saturated } \\
\hline Palmitic & 17 & 24 & 17 & 30 & 31 \\
\hline Stearic & 2 & 2 & 3 & 42 & 39 \\
\hline \multicolumn{6}{|c|}{ Monounsaturated } \\
\hline Oleic & 3 & 5 & 30 & 7 & 15 \\
\hline \multicolumn{6}{|c|}{ Polyunsaturated } \\
\hline Linoleic & 13 & 22 & 45 & 4 & 2 \\
\hline Linolenic & 61 & 47 & - & 6 & 1 \\
\hline
\end{tabular}

The contents of the duodenum pass into more distal regions of the small intestine where absorption takes place. This requires the release of fatty acids from the particulate matter and their incorporation into micelles; this is facilitated by the bile lipids and acids (see Noble, 1981). There is also some hydrolysis of phosphatidyl choline to lysophosphatidyl choline by the pancreatic phospholipases (see Noble, 1981).

In cattle and sheep most fatty acids of dietary origin are absorbed in the unesterified form, with little absorption of 2-monoacylglycerols as occurs in man and other non-ruminants (see Noble, 1981; Moore \& Christie, 1984). Within the enterocytes of the small intestine the absorbed fatty acids are esterified, primarily by the glycerol-3phosphate pathway with little being esterified by the monoacylglycerol pathway (see Noble, 1981; Moore \& Christie, 1984). Before esterification there is some desaturation of stearic to oleic acid, for in contrast to the situation in simple-stomached mammals the enterocyte in cattle and sheep has an active desaturase (see Noble, 1981; Moore \& Christie, 1984). Triacylglycerols, phospholipids and cholesterol esters are produced and used for the production of chylomicrons which are secreted into lymph. As ruminant diets are relatively low in cholesterol, the enterocyte is an important site of cholesterol synthesis in cattle and sheep (see Noble, 1981).

As would be expected of animals eating a low-fat diet, the chylomicrons in ruminants are smaller than those in man or the rat and are similar in size to very-low-density lipoproteins in simple-stomached species; much larger chylomicrons are produced when cattle and sheep are given high-fat supplements to their diets (see Noble, 1981). Triacylglycerol is the major lipid of lymph, comprising $70-80 \%$ by weight of total lipid in sheep and cattle (Christie, 1981b) and is the major source of fatty acids for tissues. As a result of biohydrogenation in the rumen, the amount of linoleic and linolenic acids in lymph (and hence plasma) triacylglycerols is very low although as a result of desaturase activity in the enterocyte there is more oleic acid in lymph triacylglycerols than in the rumen (Table 1 ).

\section{Fate of dietary fatty acids}

The lymph lipids pass into the blood via the thoracic duct. Plasma lipids actually contain substantial amounts of polyunsaturated fatty acids, but these are almost 
exclusively confined to the phospholipids and cholesterol esters whereas the triacylglycerols, which are mostly derived from lymph chylomicrons, are almost devoid of such fatty acids (Christie, 1981b). As in other mammals, tissues such as muscle, adipose and mammary gland secrete lipoprotein lipase (EC 3.1.1.34), which hydrolyses the chylomicron triacylglycerols, releasing the fatty acids for use by the tissues. Again, as in other species, fatty acids are used for the synthesis of structural components (e.g. membranes) and 'biologically-active' substances (e.g. prostaglandins) and also as a source of energy, either for use immediately, in the future (storage as adipose tissue triacylglycerols) or vicariously (secretion as milk triacylglycerols).

The amount of linoleic acid absorbed by ruminants corresponds to about $0.5 \%$ of total energy intake, whereas in other mammals a minimum intake of linoleic acid equivalent to $1-2 \%$ of dietary energy is thought to be essential to avoid the precipitation of essential fatty acid deficiency (see Noble, 1984). Ruminants, like other mammals, are unable to synthesize linoleic acid de novo. It may thus be inferred that ruminants have devised efficient means for conserving dietary linoleic acid, and indeed this fatty acid is used almost exclusively for biosynthesis of essential components with little being used for energy metabolism. Linoleic acid is essential for the synthesis of arachidonic acid, the precursor of prostaglandins, for example, while the fluidity of membranes and hence the activity of their translocase systems and their ability to respond to hormones is improved by increasing the amount of polyunsaturated fatty acids in their lipids (see Wahle, 1983). Comparison of the fatty acid composition of the phospholipid fraction of muscle (the major lipid component of membranes) and of the triacylglycerols of adipose tissue and milk (Table 2) demonstrates the selectivity with which linoleic acid is used. The selectivity lies at the level of phospholipid rather than triacylglycerol synthesis, for the fatty acid composition of muscle phospholipids differs markedly from that of plasma triacylglycerols (Table 2) (however, the use of plasma lipids other than triacylglycerols has not been rigorously excluded, see p.291). In contrast, the fatty acid composition of adipose tissue and milk triacylglycerols resembles that of plasma triacylglycerols (Table 2) (differences in the relative amounts of oleic and stearic acids arise from desaturase activity in adipose tissue and mammary gland). If the absorption of linoleic acid is increased by feeding ruminants oils rich in linoleic acid, treated to prevent biohydrogenation in the rumen, then the linoleic acid content of lymph, plasma and tissue triacylglycerols can be increased markedly (Scott \& Cook, 1974) (Table 3). Experiments in vitro have also shown that adipose tissue from ruminants will esterify palmitate and linoleic acids to triacylglycerol with equal avidity (Vernon, 1977) although other studies

\section{Table 2. Fatty acid composition of lipids of bovine blood and tissues}

(Values expressed as $\mathrm{g}$ fatty acid/100 $\mathrm{g}$ total fatty acid and are taken from Christic (1981b))

$\begin{array}{lcccc}\text { Fatty acid } & \begin{array}{c}\text { Plasma } \\ \text { triacylglycerol }\end{array} & \begin{array}{c}\text { Skeletal } \\ \text { muscle } \\ \text { phospholipids }\end{array} & \begin{array}{c}\text { Adipose } \\ \text { tissue } \\ \text { triacylglycerols }\end{array} & \begin{array}{c}\text { Milk* } \\ \text { triacylglycerols }\end{array} \\ \text { Palmitic } & 32 & 22 & 24 & 26 \\ \text { Stearic } & 32 & 8 & 13 & 15 \\ \text { Oleic } & 18 & 24 & 44 & 30 \\ \text { Linoleic } & 2 & 23 & 3 & 2 \\ \text { Linolenic } & 1 & 2 & - & 1 \\ \text { Arachidonic } & - & 12 & - & -\end{array}$

*Also $22 \mathrm{~g} / 100 \mathrm{~g}$ short- and medium-chain fatty acids (i.e. smaller than palmitic acid). 
Table 3. Effect of feeding a supplement of formaldehyde-casein protected safflower oil on triacylglycerol fatty acids of sheep adipose tissue and cow's milk

(Values are expressed as $\mathrm{g}$ fatty acid $/ 100 \mathrm{~g}$ total fatty acids and are taken from Christie (1981b))

\begin{tabular}{|c|c|c|c|c|}
\hline \multirow[b]{2}{*}{ Fatty acid } & \multicolumn{2}{|c|}{ Sheep adipose tissue } & \multicolumn{2}{|c|}{ Cow's milk } \\
\hline & $\begin{array}{c}\text { Basal } \\
\text { diet }\end{array}$ & $\begin{array}{c}\text { Basal + } \\
\text { supplement }\end{array}$ & $\begin{array}{c}\text { Basal } \\
\text { diet }\end{array}$ & $\begin{array}{c}\text { Basal + } \\
\text { supplement }\end{array}$ \\
\hline $\begin{array}{l}\text { Short- and } \\
\text { medium-chain* }\end{array}$ & 3 & 2 & 24 & 18 \\
\hline Palmitic & 19 & 11 & 30 & 16 \\
\hline Stearic & 18 & 10 & 12 & 11 \\
\hline Oleic & 45 & 39 & 24 & 24 \\
\hline Linoleic & 3 & 28 & 3 & 25 \\
\hline Linolenic & 2 & 3 & 2 & 2 \\
\hline
\end{tabular}

*Smaller (fewer carbon atoms) than palmitic acid.

suggest some discrimination against the use of linoleic acid for triacylglycerol synthesis in adipose tissue (see Vernon, 1981).

There is also evidence for oxidation of linoleic acid being limited in ruminants. Fatty acid oxidation makes a minor contribution to carbon dioxide production in fed ruminants as might be expected from the low lipid content of the diet, but on fasting there is a release of unesterified fatty acids from adipose tissue and increased fatty acid oxidation by tissues (see Bell, 1981; Pethick et al. 1984). In fasted sheep about $50 \%$ of the palmitic acid of the plasma unesterified fatty acid fraction was oxidized but only $19 \%$ of linoleic acid (Table 4). Studies with isolated liver mitochondria show a major species difference in their avidity for oxidizing palmitic and linoleic acids (Table 4). Uptake of fatty acids into the mitochondria requires their conversion to their acyl carnitine derivatives catalysed by the enzyme carnitine acyltransferase $\mathrm{I}(E C 2.3 .1 .7$; CPT I). This enzyme is inhibited by malonyl CoA, an intermediate of fatty acid synthesis (see Zammit, 1984). Malonyl CoA is much more effective in inhibiting CPT I when linoleyl CoA is substrate than when palmityl CoA is substrate in sheep liver (whereas the converse pertains in rat liver) (Reid \& Husbands, 1985) providing a mechanism for restricting oxidation of linoleic acid in sheep.

Table 4. Oxidation of palmitic and linoleic acid in sheep and rats

\begin{tabular}{|c|c|c|c|}
\hline Variable & Animal & Palmitic acid & Linoleic acid \\
\hline $\begin{array}{l}\text { Plasma unesterified fatty acid } \\
\text { Turnover ( } \mu \mathrm{g} / \mathrm{min} \text { per } \mathrm{kg} \text { body-wt) } \\
\text { Proportion oxidized to carbon dioxide }\end{array}$ & $\begin{array}{l}\text { Fasted sheep } \\
\text { Fasted sheep }\end{array}$ & $\begin{array}{l}426 \\
0.50\end{array}$ & $\begin{array}{l}52 \\
0 \cdot 19\end{array}$ \\
\hline $\begin{array}{l}\text { Isolated liver mitochondria } \\
\text { Rate of fatty acid oxidation to } \mathrm{CO}_{2} \\
\text { ( } \mu \mathrm{mol} \mathrm{O}_{2} \text { consumed/h per } \mathrm{mg} \text { mitochondrial protein) }\end{array}$ & $\begin{array}{c}\text { Sheep } \\
\text { Rat }\end{array}$ & $\begin{array}{l}1 \cdot 4 \\
1 \cdot 4\end{array}$ & $\begin{array}{l}1 \cdot 0 \\
2 \cdot 2\end{array}$ \\
\hline $\begin{array}{l}\text { Liver, carnitine acyltransferase I ( } E C \text { 2.3.1.7) } \\
\text { Activity in presence of malonyl CoA } \\
\text { as a proportion of the activity in the absence of } \\
\text { malonyl CoA }\end{array}$ & $\begin{array}{l}\text { Sheep } \\
\text { Rat }\end{array}$ & 0.50 & $\begin{array}{l}0.05 \\
0.80\end{array}$ \\
\hline
\end{tabular}

Values from Lindsay \& Leat (1977) and Reid \& Husbands (1985). 
The liver appears to have a minor role in the secretion of triacylglycerol (as a component of very-low-density lipoprotein) in ruminants (see Bell, 1981) but it probably contributes to the production of plasma lipoprotein phospholipids, which as noted previously are rich in polyunsaturated fatty acids. Sparing linoleic acid from oxidation should favour its use for phospholipid synthesis. The phospholipids of plasma lipoproteins are not thought to contribute fatty acids for use by tissues, but recent studies with rats show that the liver can also secrete lysophosphatidylcholine (Sekas et al. 1985; Graham et al. 1988) and other studies with non-ruminants show that it can be taken up by tissues and used for phospholipid synthesis (Illingworth \& Portman, 1972; Savard \& Choy, 1982). The plasma lipids of sheep contain 2-3 g lysophosphatidylcholine $/ 100 \mathrm{~g}$ (Christie, 1981) and this lipid is relatively rich in linoleic acid (Noble et al. 1972). Use of plasma lysophosphatidylcholine rather than triacylglycerol fatty acids for the production of membrane phospholipids might thus account for the relatively high linoleic acid content of membrane phospholipids in ruminants.

\section{Fatty acid synthesis}

Microbial metabolism in the rumen also has consequences for fatty acid synthesis in ruminants, as essentially all dietary carbohydrates are metabolized to short-chain fatty acids (acetate, propionate and butyrate) (see Harfoot, 1981). Consequently the liver is committed to gluconeogenesis to make up for the lack of dietary glucose, and fatty acid synthesis is very low in this tissue (it is sufficient to maintain enough malonyl CoA to modulate fatty acid oxidation, Brindle et al. 1985). Adipose tissue is the major site of fatty acid synthesis in ruminants except during lactation when, in ruminants and non-ruminants alike, the mammary gland becomes the predominant site (see Vernon \& Flint, 1983). Also, acetate rather than glucose is the major precursor for fatty acid synthesis in ruminant tissues, although there is a requirement for glucose to provide some NADPH via the pentose phosphate cycle for fatty acid synthesis, while glucose is the only source of glycerol-3-phosphate in adipose tissue and the major source in the mammary gland for fatty acid esterification (see Moore \& Christie, 1981; Vernon, 1981).

The major control point of fatty acid synthesis in both ruminants and non-ruminants is acetyl-CoA carboxylase ( $E C$ 6.4.1.2) (Vernon \& Flint, 1983) and it seems that, in adipose tissue at least, the endocrine control is very similar (activation by insulin, inhibition by catecholamines) in ruminants and in non-ruminants. In contrast, in the mammary gland insulin modulates acetyl CoA carboxylase in the rat but has no effect on fatty acid synthesis in the ruminant (see Vernon \& Flint, 1983). Fatty acids, or at least their acyl $\mathrm{CoA}$ esters, inhibit acetyl $\mathrm{CoA}$ carboxylase in adipose tissue (see Vernon, 1981) and mammary gland (see Moore \& Christie, 1981) from both ruminants and non-ruminants, but as yet no hormone has been identified which acts directly on the mammary gland to inhibit fatty acid synthesis in the short term in any species.

\section{Lipolysis}

The triacylglycerols of adipose tissue are hydrolysed by hormone-sensitive lipase. This enzyme is activated by catecholamines (acting via $\beta$-adrenergic receptors) and inhibited by insulin; these properties are common to the enzyme of both ruminant and non-ruminant adipose tissues (see Vernon, 1981).

\section{Manipulation of the composition and amount of milk and adipose tissue triacylglycerols}

Triacylglycerols in both the mammary gland and adipose tissue are synthesized using fatty acids derived from the triacylglycerols of plasma chylomicrons and very-low-density 
lipoproteins released by the action of lipoprotein lipase, and fatty acids produced by de novo synthesis. Increased availability of dietary fatty acids suppresses de novo synthesis, probably by inhibition of acetyl CoA carboxylase (see Moore \& Christie, 1981; Vernon, 1981; Palmquist, 1984). This results in some variation in the fatty acid composition of the triacylglycerols, especially in milk where the proportion of short-and medium-chain fatty acids is reduced. Increasing the proportion of polyunsaturated fatty acids in these triacylglycerols, however, depends on limiting biohydrogenation of dietary lipids. Giving lipid supplements rich in polyunsaturated fatty acids results in some escaping hydrogenation and a marginal increase in the amount of polyunsaturated fatty acids in milk fat (Banks et al. 1983), but a substantial increase is dependent on protecting the lipids (e.g. by coating with casein and treating with formaldehyde) against biohydrogenation (Scott \& Cook, 1975).

Until recently, research on milk-fat production has been directed at increasing the amount of milk fat. Diets rich in concentrates are known to tend to depress the milk-fat concentration with a concomitant increase in fat deposition in adipose tissue (see Bell, 1981). Giving dietary supplements of cod-liver oil also decreases milk-fat production in cattle; decreased fatty acid synthesis is partly, but not entirely, responsible (see Christie, 1981c).

Several approaches are being developed to reduce the amount of adipose-tissue triacylglycerol in farm animals. Administration of $\beta$-agonists such as clenbuterol (Baker et al. 1984; Ricks et al. 1984) or of somatotropin (see Bauman \& McCutcheon, 1986; Johnsson $e$ al. 1987) lead to a diminution in the amount of adipose-tissue fat. $\beta$-Agonists inhibit fatty acid synthesis and stimulate lipolysis in adipose tissue (Thornton et al. 1985; Peterla et al. 1987), probably by the same mechanism as catecholamines (activation of adenylate cyclase ( $E C 4$ 4.6.1.1) and cyclic AMP-dependent protein kinase ( $E C$ 2.7.1.37), leading to phosphorylation and activation of hormone-sensitive lipase and phosphorylation and inactivation of acetyl CoA carboxylase). Growth hormone also inhibits fatty acid synthesis and promotes lipolysis in adipose tissue of ruminants (see Vernon, 1981; Bauman \& McCutcheon, 1986) but the mechanism is unknown. Activation of adenylate cyclase does not appear to be involved. Rather the hormone appears to act as an insulin-antagonist with respect to activation of acetyl-CoA carboxylase (Vernon et al. 1988) and to increase the responsiveness of the tissue to the lipolytic effect of catecholamines (McCutcheon \& Bauman, 1986).

Another approach to diminish adiposity is to inject antibodies to the adipocyte plasma membrane (Futter \& Flint, 1986). This differs from the approaches described previously in that the effect results from the destruction of adipocytes rather than the manipulation of lipid metabolism; consequently it provides a potential means of permanently reducing adiposity.

\section{Conclusions}

The development of a rumen and its constituent population of micro-organisms has enabled ruminant animals to succeed on a herbivorous diet. However, as a concomitant of this, extensive biohydrogenation of dietary polyunsaturated fatty acids by rumen micro-organisms has necessitated adaptations to survive on a diet deficient (by nonruminant standards) in essential fatty acids. Microbial metabolism in the rumen is a major obstacle to manipulating the fatty acid composition of ruminant lipids by dietary means. However, endocrinological and immunological manipulations provide means for decreasing the amount of triacylglycerols in ruminant tissues. 


\section{REFERENCES}

Baker, P. K., Dalrymple, R. H., Ingle, D. L. \& Ricks, C. A. (1984). Journal of Animal Science 59, 1256-1261. Banks, W., Clapperton, J. L. \& Steele, W. (1983). Proceedings of the Nutrition Society 42, 399-406.

Bauman, D. E. \& McCutcheon, S. N. (1986). In Control of Digestion and Metabolism in Ruminants, pp. 436-455 [L. P. Milligan, W. L. Grovum and A. Dobson, editors]. New Jersey: Prentice Hall.

Bell, A. W. (1981). In Lipid Metabolism in Ruminant Animals, pp. 363-410 [W. W. Christie, editor]. Oxford: Pergamon Press.

Brindle, N. P. J., Zammit, V. A. \& Pogson, C. I. (1985). Biochemical Journal 232, 177-182.

Christie, W. W. [editor] (1981a). Lipid Metabolism in Ruminant Animals. Oxford: Pergamon Press.

Christie, W. W. (1981b). In Lipid Metabolism in Ruminant Animals, pp. 95-191 [W. W. Christie, editor]. Oxford: Pergamon Press.

Christie, W. W. (1981c). In Lipid Metabolism in Ruminant Animals, pp. 193-226 [W. W. Christie, editor]. Oxford: Pergamon Press.

Futter, C. E. \& Flint, D. J. (1986). In Recent Advances in Obesity Research, vol. 5, pp. 181-185 [E. M. Berry, S. H. Blondheim, H. E. Eliahou and E. Shafrir, editors]. London: John Libbey.

Graham, A., Zammit, V. A. \& Brindley, D. N. (1988). Biochemical Journal 249, 727-733.

Harfoot, C. G. (1981). In Lipid Metabolism in Ruminant Animals, pp. 21-55 [W. W. Christie, editor]. Oxford: Pergamon Press.

Illingworth, D. R. \& Portman, O. W. (1972). Biochemical Journal 130, 557-567.

Johnsson, I. D., Hathorn, D. J., Wilde, R. M., Treacher, T. T. \& Butler-Hogg, B. W. (1987). Animal Production 44, 405-414.

Lindsay, D. B. \& Leat, W. M. F. (1977). Journal of Agricultural Science, Cambridge 89, 215-221.

McCutcheon, S. N. \& Bauman, D. E. (1986). Journal of Diary Science 69, 44-51.

Moore, J. H. \& Christie, W. W. (1981). In Lipid Metabolism in Ruminant Animals, pp. 227-277 [W. W. Christie, editor]. Oxford: Pergamon Press.

Moore, J. H. \& Christie, W. W. (1984). In Fats in Animal Nutrition, pp. 123-149 [J. Wiseman, editor). London: Butterworths.

Noble, R. C. (1981). In Lipid Metabolism in Ruminant Animals, pp. $57-93$ [W. W. Christie, editor]. Oxford: Pergamon Press.

Noble, R. C. (1984). In Fats in Animal Nutrition, pp. 185-200 [J. Wiseman, editor]. London: Butterworths.

Noble, R. C., O’Kelly, J. C. \& Moore, J. H. (1972). Biochimica et Biophysica Acta 270, 519-528.

Palmquist, D. L. (1984). In Fats in Animal Nutrition, pp. 357-381 [J. Wiseman, editor]. London: Butterworths.

Peterla, T. A., Ricks, C. A. \& Scanes, C. G. (1987). Journal of Animal Science 65, Suppl. 1, 278.

Pethick, D. W., Bell, A. W. \& Annison, E. F. (1984). In Fats in Animal Nutrition, pp. 225-248 [J. Wiseman, editor]. London: Butterworths.

Reid, J. C. W. \& Husbands, D. R. (1985). Biochemical Journal 225, 233-237.

Ricks, C. A., Dalrymple, R. H., Baker, P. K. \& Ingle, D. L. (1984). Joumal of Animal Science 59, 1247-1255.

Savard, J. E. \& Choy, P. C. (1982). Biochimica et Biophysica Acta 711, $40-48$.

Scott, T. W. \& Cook, L. J. (1975). In Digestion and Metabolism in the Ruminant, pp. 510-523 [1. W. McDonald and A. C. I. Warner, editors]. Armidale: University of New England Publishing Unit.

Sekas, G., Patton, G. M., Lincoln, E. C. \& Robins, S. J. (1985). Journal of Laboratory and Clinical Medicine 105, 190-194.

Thornton, R. F., Tume, R. K., Payne, G., Larsen, T. W., Johnson G. W. \& Hohenhaus, M. A. (1985). Proceedings of the New Zealand Society of Animal Production 45, 97-101.

Vernon, R. G. (1977). International Journal of Biochemistry 8, 517-523.

Vernon, R. G. (1981). In Lipid Metabolism in Ruminant Animals, pp. 279-362 [W. W. Christie, editor]. Oxford: Pergamon Press.

Vernon, R. G., Barber, M., Finley, E. \& Grigor, M. R. (1988). Proceedings of the Nutrition Society 47, 100A.

Vernon, R. G. \& Flint, D. J. (1983). Proceedings of the Nutrition Society 42, 315-331.

Wahle, K. W. J. (1983). Proceedings of the Nutrition Society 42, 273-287.

Wiseman, J. (1984). Fats in Animal Nutrition. London: Butterworths.

Zammit, V. A. (1984). Progress in Lipid Research 23, 39-67. 